\title{
Image of China in Slovakia: ambivalence, adoration, and fake news
}

\author{
Matej Šimalčík ${ }^{1,2}$ (D)
}

Received: 4 September 2019 / Revised: 6 October 2020 / Accepted: 5 February 2021/ Published online: 3 March 2021

(C) The Author(s), under exclusive licence to Springer-Verlag GmbH, DE part of Springer Nature 2021

\begin{abstract}
The paper looks into the image of China in Slovakia. Following the period of relative disinterest of the media in majority of topics connected with China, media are starting to pay increasingly more attention towards China and various aspects of its development, domestic policy, and foreign affairs. Increased media coverage of China begs to ask the question what image of China the Slovak media are presenting to the public. The proposed article draws upon an extensive database of media pieces published or broadcasted by Slovak newspapers, TV stations, radios, as well as online media outlets in the period of 2010-2017. Using the method of qualitative content analysis, a selection of over 2600 media pieces are analyzed and coded for general sentiments and themes covered in the media. Secondly, the paper also analyzes the perception of China among Slovak political elites, drawing on interviews with key stakeholders among the most important political parties, as well as public perception based on several opinion surveys. The article concludes that while negative perception of China prevails in the media and among the public, it is not complex and prone to change. On the level of political parties, three distinct groups exist, defined by their levels of pragmatism and pro-China positions (pragmatic supporters, ideological supporters, and ideological opponents).
\end{abstract}

\section{Introduction}

At least since 2012, Slovakia, as well as its Visegrad neighbors and other countries in the wider Central and Eastern Europe (CEE), has been observing increasing presence of China in the region. The increasing Chinese presence materialized in increasing trade volumes and investments between China and CEE. Nevertheless, the rise in trade volume is still mostly on the part of Chinese exports to $\mathrm{CEE}$, thus contributing to

Matej Šimalčík

simalcik@ceias.eu

1 Central European Institute of Asian Studies, Murgašova 2, 81104 Bratislava, Slovakia

2 Palacky University in Olomouc, Olomouc, Czech Republic 
negative trade balance of the CEE countries, and the stock of Chinese investments in the region is far below the expectation the CEE countries had when they started to cooperate more closely with China. Likewise, the engagement of China with CEE has so far resulted only in very few investment opportunities in China for CEE firms. The actual stock of CEE foreign direct investments (FDI) in China has reached only meager 1.4 billion US Dollars for all the 16 CEE countries combined (Xinhua 2018).

Both the economic and political relations between China and the CEE have been dealt with under the so-called $16+1$ Platform which groups China with 16 countries of the CEE. The platform was initiated in 2012 under the auspice of then Chinese Premier Wen Jiaboao, who met with the representatives of CEE countries in Warsaw. Since then, seven $16+1$ summits took place. While the $16+1$ platform predates the Belt and Road Initiative (BRI), it has since been incorporated under the BRI umbrella.

The $16+1$ platform has been on many occasions decried by policymakers, pundits, and analysts in Western Europe for breaking the EU from within (11 of the $16 \mathrm{CEE}$ countries are EU members, all of them are new member states that acceded to the EU in 2004 or later) and took it as evidence of China using a divide et impera tactics in Europe. Questionable decisions of some of those 11 countries (especially Hungary and Czech Republic) in questions such as human rights abuses in China, BRI, or South China Sea have reinforced this perception, which were motivated by the lure of Chinese investments (Šimalčík 2018), served to reinforce this perception on part of Western Europeans. Empirical evidence suggests that this view is largely exaggerated (Matura 2015).

These are some of the factors that influence the perception of China in the CEE. In this regard, media serve as an important intermediary that supply information for the public and frame it as part of the bigger picture. By supplying information, the media shapes the people's worldviews, and by doing so, it shapes the in-group and out-group identity. As a result, our views about who are our allies and enemies are influenced (Coban 2016). Moreover, by influencing the public perception, the media can influence the process of issue securitization, a process by which actors frame issues as threats to their survival (Buzan et al. 1998, 23-26). The success of securitization largely depends on the significant portion of the audience concurring with the views of the securitizing actor (Balzacq 2005). By providing information to the audience, the media influences the outcome of the securitization attempt when it either echoes the securitizing actor's concerns or provides alternative opinions to the audience.

This begs to ask the question how media in individual CEE countries present China and various aspects of its policies and behavior. This paper looks into the media perception in the case of Slovak republic. How is China presented in the media? What topics dominate the Slovak media discourse on China? Who are its dominant actors? These are the key questions this paper asks. In order to answer them, the paper draws on a dataset of over 2600 media outputs over the course of 7 years (2010-2017). ${ }^{1}$ These were coded for their overall sentiment (negative, neutral, or positive) and topics covered. Secondly, the paper analyzes public communication of the Chinese embassy in Slovakia in order to determine the topics of importance for Beijing. By comparing

\footnotetext{
${ }^{1}$ This dataset was produced as part of project MapInfluenCE, a joint undertaking between the Central European Institute of Asian Studies, Association for International Affairs, and Central and Eastern European Centre of Asian Studies that is supported by the National Endowment for Democracy. The media outputs include television, radio, newspapers, weekly magazines, and online media and were selected based on their market share. The period covers 2010 to mid-2017. For more information, see www.mapinfluence.eu.
} 
the Chinese communication with the overall coverage of the same topics, we can determine how successful the embassy is in getting its message across to the Slovak public. Thirdly, the paper also analyzes the views of Slovak politicians, as they are the ones who determine the actual Slovak policy towards China. Fourthly, the paper investigates the perception of China among the general public.

\section{China in mainstream media ${ }^{2}$}

When it comes to covering China, Slovak media focus mostly on covering economic topics, chiefly on reporting the figures of growth rates of Chinese economy and other economic indices. Such reporting does not offer much insight for the Slovak public as most of these articles do not link macroeconomic reporting with any other topic. It should come as no surprise then that majority of Slovak coverage of China is neutral. In fact, as many as $68 \%$ of all the articles on China are neutral. Of the remaining portion of media coverage, majority is negative (26\%) and only a small portion spreads positive image of China (6\%). Only one type of media in Slovakia did not conform to this trend. Tabloids presented a much more negative image of China compared to other media. In tabloids, the share of negative articles was much higher compared to the rest of the analyzed media. In fact, there were more negative articles than neutral ones in tabloid media. At the same time, the share of positive pieces was also higher compared to other types of media. This shows there is a high level of polarization of coverage of China in tabloids. However, this is a normal occurrence as it is in the very nature of tabloids to present topics in a sensationalist style while appealing to the readers' (mostly negative) emotions. The tabloid coverage does not get much traction though as it represents only some $2 \%$ of the overall coverage volume.

From a regional perspective, Slovak media discourse significantly differs from neighboring Czechia and Poland, while being somewhat similar to the media discourse in Hungary. In Czechia, $41 \%$ of articles were negative, $14 \%$ positive, and $45 \%$ neutral - a composition which is actually similar to the narrative of Slovak tabloid media. Unlike Czechia, the Polish discourse is quite the opposite-39\% of articles were positive while only as little as $3 \%$ were negative; $58 \%$ articles were neutral. Of all the Central European countries, the Hungarian discourse resembles the Slovak one the most - only 5\% articles were positive, $9 \%$ were negative, and $86 \%$ neutral (Fig. 1). ${ }^{3}$

As was already mentioned, Slovak media discourse on China is focused mostly on economic topics. The Chinese economy was discussed 1.7 times more often than Chinese foreign policy, and 2.1 times more often than Chinese domestic politics and policies. Among the top five topics covered by the media, only a single topic was not related to the economy but rather to domestic policy. Security-related topics are seriously underrepresented in the media discourse. The reason for the thematic imbalance in the media coverage is connected to the composition of the actors involved in the media debate, where economists have a dominant position in the media discourse.

\footnotetext{
${ }^{2}$ For a more extensive discussion of media coverage in Slovakia, see the website of project MapInfluenCE at www.mapinfluence.eu and accompanying policy paper by Karásková et al. (2018).

3 The comparison draws on the MapInfluenCE dataset, which contains data on media coverage of China in Slovakia, Czechia, Poland, and Hungary from the period of 2010-2017.
} 


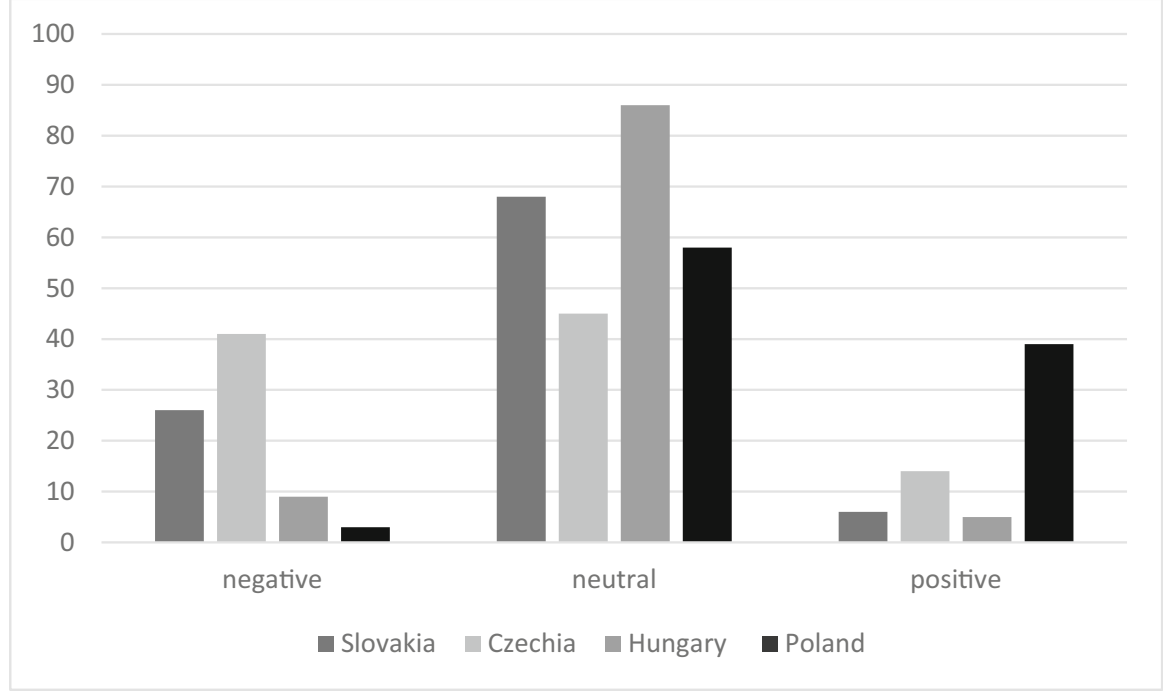

Fig. 1 Sentiment of media coverage of China across Central European countries ( $\%$ of articles)

Discounting the neutral coverage, there is more negative coverage of China then positive. In fact, the negative coverage is over four times larger than positive. This does not mean, though, that such composition holds true for all the main topics covered in the analyzed articles. Table 1 shows all the identified topics in the analyzed articles, their share in the overall China discourse, and the sentiment value of each topic. ${ }^{4}$ As can be seen from the table, topics related to human rights and territorial disputes received the most negative coverage of all the topics. Only a handful of topics were covered more positively rather than negatively. Chinese culture and history, Belt and Road Initiative, and $16+1$ platform are the only three positively covered topics. The positive sentiment is however still very close to neutral sentiment.

Several of the topics which appeared in the Slovak media are related to what can be labeled as Chinese core interests. In an authoritative discussion of Chinese core interests, former State Councilor Dai Bingguo identified three core interests which act both as motivations for Chinese foreign policy and behavior as well as red lines for behavior of others that China is not willing to tolerate. The three core interests are regime security, sovereignty and territorial integrity, and socio-economic development (Dai 2010). Of the three, regime security is the ultimate core interest which is supported by the remaining two core interests.

Regime security refers to the demand for the survival of the one-party regime of the Chinese Communist Party with the "socialism with Chinese characteristics" as the leading ideology. Under the header of socio-economic development of China fall topics such as Chinese investments, Chinese economic growth, trade, and Chinese economic policies. Subsequently, under the header of sovereignty and territorial integrity fall topics related to territorial disputes, Tibet, Xinjiang and Uyghurs, Hong Kong, or Macao.

\footnotetext{
${ }^{4}$ This has been calculated as an average of sentiment values of each article ( -1 for negative, 0 for neutral, 1 for positive).
} 
Table 1 Sentiment of topics covered in the Slovak media discourse on China

\begin{tabular}{|c|c|c|}
\hline Topic & Sentiment & Volume $(\%)^{\mathrm{a}}$ \\
\hline Culture \& history of China & 0.111111 & 2.1 \\
\hline Belt and Road Initiative & 0.089286 & 2.2 \\
\hline $16+1^{b}$ & 0.045455 & 0.8 \\
\hline Foreign investments in China & 0 & 2.1 \\
\hline Research \& development & 0 & 1.8 \\
\hline Chinese investments & -0.01293 & 8.9 \\
\hline Sino-Czech relations & -0.13333 & 2.9 \\
\hline Trade & -0.13636 & 15.2 \\
\hline Economic growth & -0.13749 & 41.9 \\
\hline Sino-American relations & -0.15385 & 8.0 \\
\hline Chinese influence in the world & -0.15445 & 14.7 \\
\hline Foreign policy & -0.15576 & 12.3 \\
\hline EU-China relations & -0.15847 & 7.0 \\
\hline Economic policy & -0.15982 & 33.7 \\
\hline Sino-Slovak relations & -0.17453 & 8.1 \\
\hline State of Chinese economy & -0.20725 & 7.4 \\
\hline Chinese market & -0.22287 & 26.5 \\
\hline Environment & -0.24286 & 2.7 \\
\hline Family and social policy & -0.26923 & 8.0 \\
\hline Territorial disputes & -0.28125 & 3.7 \\
\hline Taiwan & -0.28358 & 2.6 \\
\hline Domestic policy & -0.2891 & 16.2 \\
\hline Macao & -0.33333 & 0.1 \\
\hline Communism & -0.39544 & 10.1 \\
\hline Espionage & -0.41379 & 1.1 \\
\hline Uyghurs & -0.47059 & 1.3 \\
\hline Human rights & -0.5 & 8.4 \\
\hline Tibet & -0.50595 & 6.5 \\
\hline Hong Kong & -0.56522 & 0.9 \\
\hline
\end{tabular}

a Volume here denotes the share of articles in the sample which cover a specific topic. As single article can cover more than one topic, the shares should be treated individually for each topic (hence, they can add up to over 100 percent)

b $16+1$ refers to the cooperation mechanism between China and 16 countries of Central and Eastern Europe, comprising $11 \mathrm{EU}$ member states and 5 non-EU countries from Western Balkans. In 2019, the platform was joined by Greece and thus changing the moniker to $17+1$. As this paper examined period prior to Greece's joining of the platform, the original moniker is used

Of the two core interests, socio-economic issues are viewed in a much more positive light than the sovereignty-related issues. This is to a large extent caused by the fact that the sovereignty-related issues are usually connected with human rights (Tibet, Uyghurs) or democratic principles of government (Taiwan). As the views of the Slovak elites and journalists are predominantly liberal-democratic, it is quite predictable that they would be in opposition to Chinese views on the sovereignty-related issues. 
Of the sovereignty issues, Tibet has received by far the largest amount of coverage, as the topic appeared in some $6.5 \%$ of analyzed media outputs. Most of those articles were actually published in a short time span. Almost half of all Tibet-related pieces were published in late 2016 as a result of Dalai Lama visiting Slovakia and holding a private, personal, and non-official meeting with Slovak President Andrej Kiska. The visit was naturally met with vitriolic reactions from Chinese officials. A more interesting fact is that this is probably the only time when China has entered domestic political discourse as the meeting became a cause of sharp conflict between President Kiska and then Prime Minister Fico. Fico would even refer to the incident on several occasions after the event happened and was probably forgotten by most ordinary Slovaks whenever Kiska would be criticizing the government led by Fico, citing it as a proof that Kiska does not work towards promotion of Slovak national interests abroad (TASR 2016).

\section{Slovak disinformation scene}

Chinese presence in Slovakia is often likened to the Russian one. Russian influence is often discussed in relation to Slovak disinformation scene and the various media that are supported from Russia. Hlavné správy, Parlamentné listy, Zem a vek, or Nové slovo are few examples of such media. ${ }^{5}$ These media gain following based on the claim that they provide readers with alternative interpretation of events, both domestic and foreign, and offer coverage of topics that, as they put it, is not allowed to be published in mainstream media.

The dataset on which the analysis in the previous section was based contains also data on two of the disinformation media-Hlavné správy and Parlamentné listy. The analysis revealed that they do not differ that much from the mainstream media in their coverage of China. Hlavné správy actually published a higher share of negative average than the average on the entire media scene in Slovakia (34\% in case of Hlavné správy versus $24 \%$ in all analyzed media) while the share of positive pieces remained virtually the same. With Parlamentné listy, the situation is a bit different. There is a little bit more positive coverage than negative (19\% and $15 \%$ respectively), but the largest share remains with the neutral pieces $(66 \%)$.

Yet, when one digs deeper into the coverage presented by the two media, a different picture emerges. In their aim to spread disinformation, the two media rely on tactic of flooding the audience with too much information and thus creating doubts about the nature and validity of information, which in turn results in decreasing trust of the audience in public institutions. This is done by reposting articles from other media and press agency reporting. This helps to explain why the two media have similar composition of the China-related coverage compared to mainstream media. The disinformation is found only after conducting in-depth qualitative research.

\footnotetext{
5 The classification of media as disinformation and conspiracy theory outlets is based on the media database maintained by Konspiratori.sk, a media watchdog initiative which monitors online media and ranks them based on prevalence of disinformation. The four media mentioned here all appeared on the list of disinformation outlets during the examined period. Parlamentné listy and Nové slovo were since then removed from the list due to improvements in the quality of their content. For more information see https://www.konspiratori. sk/en/.
} 
On several instances, Hlavné správy published two interviews with Chinese ambassador in Slovakia. The two interviews were published following the meeting between President Kiska and Dalai Lama and thus we can view them as a form of rebuttal. The two articles naturally presented the official Chinese position on the Tibet issue as well as some other issues - South China Sea, Belt and Road Initiative, conflict in Syria, etc. (Lin 2016b; Lin 2016c). What is more problematic though is the very fact that they appeared in Hlavné správy. The medium is known to be supported by Russia and serves as one of the main channels for Russian propaganda. By using an outlet like Hlavné správy to get its message across, the Embassy of China legitimized the outlets very existence and thus offered a tacit support to the Slovak disinformation scene (Mesežnikov and Pleschová 2017).

Similar articles attributable to Chinese embassy appeared also in Nové slovo, another disinformation portal known for its Russian ties. The portal, for example, published an op-ed by Chinese ambassador on the topic of South China Sea. The article appeared after an international tribunal decided against China in a case brought by the Philippines. In the article, Ambassador Lin Lin promoted official Chinese views on the issue (Lin 2016a).

The above serves as an example of disinformation media serving as tools for spreading the official Chinese line on contentious issues. However, this is not always true as these media, in their fervor to support China, sometimes present opinions which actually go against the official Chinese views. An example is recent reporting by Hlavné správy on the Sofia Summit of $16+1$. Here, Parlamentné listy reported a story about how China helped Serbia to hoodwink EU. However, this is not in line with the official Chinese narrative, which stresses that $16+1$ is beneficial to EU integration rather than going against it (Dubravčíková et al. 2018).

Hong Kong protests against the extradition law in 2019 have provided a cause for the Chinese embassy in Slovakia to move the disinformation campaigns from fringe media towards the media mainstream. Local business focused magazine Trend published an advertorial, a paid-for content in the form of an op-ed, attributed to the Chinese ambassador in Slovakia. In the article, he described the protesters in Hong Kong as terrorists supported by foreign forces (Šimalčík 2019).

\section{Views of political representation}

Overall, China does not feature highly on the agenda of Slovak political representation. China appears in the Slovak political discourse only rarely (abovementioned case of Dalai Lama's meeting with President Kiska is one such case). Indeed, when we examined the Slovak media discourse, politicians rarely commented on China. Among 76 stakeholders who voiced their opinion on China at least three times in 2010-2016/ 2017 period, only 3 politicians appeared (Turcsányi and Šimalčík 2018).

Examining political program documents of Slovak political parties reveals only scarce mentions of China. Probably the most extensive description of how a party wishes to engage with an increasingly more powerful China is contained in a foreign policy program developed by a non-parliamentary, newly established party SPOLUobčianska demokracia (TOGETHER-Civic Democracy). The leitmotif of the document Successful Slovakia in an Uncertain World is Slovakia's anchoring in Western 
civilization and belonging to the Euro-Atlantic grouping of states. This is echoed in the section on China as well, as the document proposes that "we [Slovakia] can help turn China into a responsible stakeholder in global decision making" (Beblavý et al. n.d.). The rise of China is viewed as a challenge to the global West. SPOLU recognizes the dichotomy in Chinese behavior, whence Chinese leaders propose that China is willing to support the preservation of current international system, while at the same time it "acts aggressively in its neighborhood, especially when it comes to its expansion in South China Sea." Thus, Slovakia, as part of EU and the global West, should appeal to China to use its influence responsibly, and also should support human rights and rule of law in China.

As for other parties, there is not enough documentary evidence as to their views of China. Regarding current government coalition (Smer-SD, Slovak National Party, and Most-Hid), some views can be deduced from the fact that it is their government which passed the strategic documents on China. The economic focus of the document suggests a high level of pragmatism of these parties vis-à-vis China.

Looking at the statements by two consecutive prime ministers from the Smer-SD party, Robert Fico and Peter Pellegrini, it is evident that they view China mostly in economic terms as an opportunity for attracting new investments. This pragmatism can at time conflict with the views of the more idealist politicians. A notable example is the conflict between Fico and Kiska over Dalai Lama's visit in 2016, which was already described above. Interestingly, in pursuing pragmatist economic policy towards China, a narrative convergence between Chinese and Slovak representatives has been occurring. After the 2018 Sofia Summit of the $16+1$ platform, Prime Minster Pellegrini has been basically echoing Chinese position in the benefits of the platform and its relations to the broader EU-China relation (Dubravčíková et al. 2018).

Yet, not all members of the abovementioned parties subscribe to such a pragmatist view. A notable example is the Member of Parliament for the Smer-SD party, Luboš Blaha. A self-described Marxist, Blaha often promotes views that are opposing the USA, globalization, and liberalism, and defends Marxism and communist rule in Czechoslovakia before the 1989. Only recently, Blaha went to China to present his book "An Antiglobalist" - the irony being that today's China is a staunch supporter of globalization; hence, Blaha was going against the Chinese official line.

A similar case can be made also about Milan Uhrík, a member of parliament for the neo-Nazi party Kotleba-People's Party Our Slovakia. In 2016, Uhrík visited China at the invitation of the Henan provincial government. In his Facebook posts from the visit, Uhrík praised Chinese state-owned enterprises and their efficiency, which in Uhrík's words protects China from foreign colonizers and Chinese people from capitalistic pillage, despite the fact that the inefficiency of these enterprises has been repeatedly mentioned by the official state-owned media in China. Moreover, Uhrík praised the communist government of China, while at the same time denouncing the EU. Similar to Blaha, Uhrík also made paradoxical statements in his praise of China. According to him, there is virtually no corruption in the country, which runs contrary to the notoriously known anti-corruption campaign of Xi Jinping that calls for a stricter investigation of corruption within the Communist Party of China and state administration (Uhrík 2016).

However, views of adoration akin to those of Blaha and Uhrík are not at all common among Slovak politicians. Many of the opposition politicians actually hold quite anti- 
Chinese views determined by their support for human rights and democracy, which in turn shapes their support of Taiwan.

To illustrate, when in 2017 an exhibition of dead bodies was planned in Bratislava, several activists and politicians opposed it on account that the bodies were probably from China. Ondrej Dostál, a conservative opposition member of parliament (OKS party), raised issue of human rights and thus lobbied for prohibiting the exhibition (SITA 2017).

Negative views of China were also articulated by Martin Poliačik, a liberal opposition politician (formerly SaS party, now Progressive Slovakia party). His negative views of China were pronounced in his comments on the state of human rights in Tibet. Similar views were expressed also by his former fellow party member Stefan Osuský (Parlamentné listy 2017). Poliačik, Osuský, and couple other legislators even founded a parliamentary Friends of Tibet Club. Club members at one point hanged a flag of Tibet in the Slovak parliament and called on Chinese government to enter into dialogue with the Tibetan government in exile (TASR 2014).

\section{Public perception of China}

When it comes to general population, there are only few metrics available which offer insights into how Chinese presence in the media, as well as description of China provided to the public by local Slovak politicians, influences the popular perception of China.

Data from the Special Eurobarometers on Future of Europe (European Commission 2016, 2017, 2018) offers only the most basic insights into public perception of China in Slovakia. Comparison of data across three available years shows that the positive perception of China is somewhat volatile, while the amount of people seeing China negatively is decreasing, despite the fact that Slovak media tend to portray China rather negatively than positively (Fig. 2).

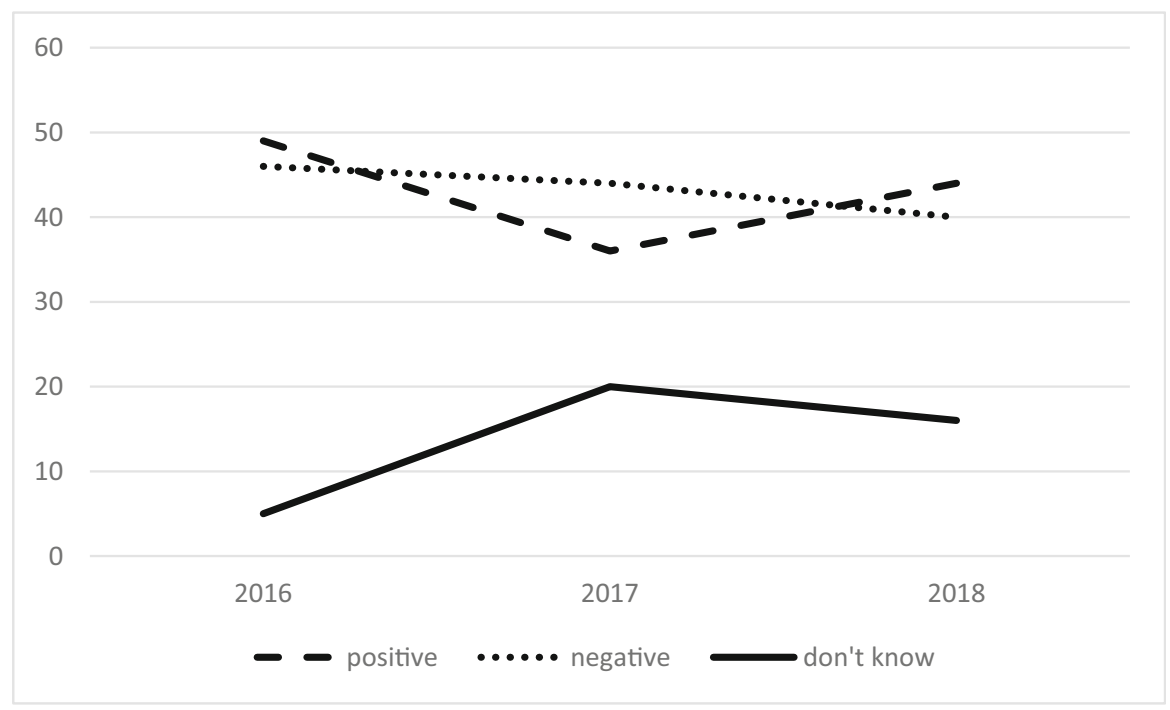

Fig. 2 Perception of China among Slovak public, data: European Commission (2016, 2017, 2018) 


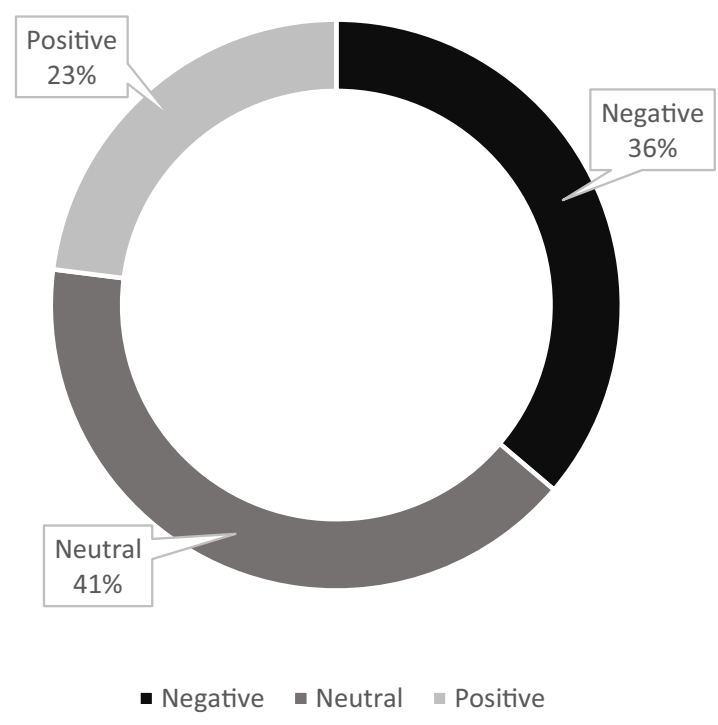

Fig. 3 Perception of China among the Slovak public in 2020, data: Turcsanyi et al. (2020)

The COVID-19 pandemic has the potential to act as an important catalyst affecting a change in the public perception of China. Polling on perception of Chinese supplies of medical equipment, conducted in late March 2020, has shown that over 67\% of Slovaks

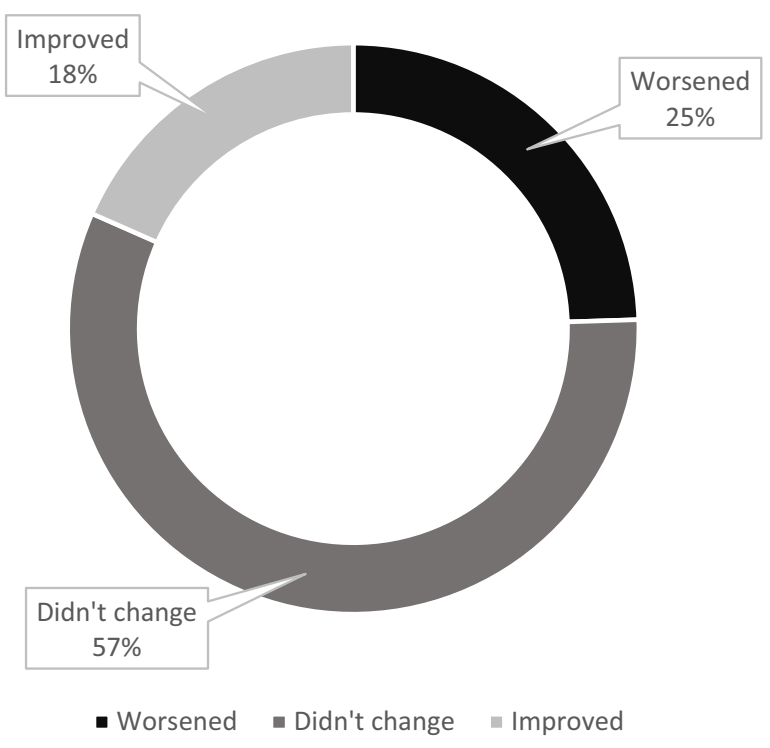

Fig. 4 Change in perception of China among the Slovak public in the last 3 years prior to 2020, data: Turcsanyi et al. (2020) 


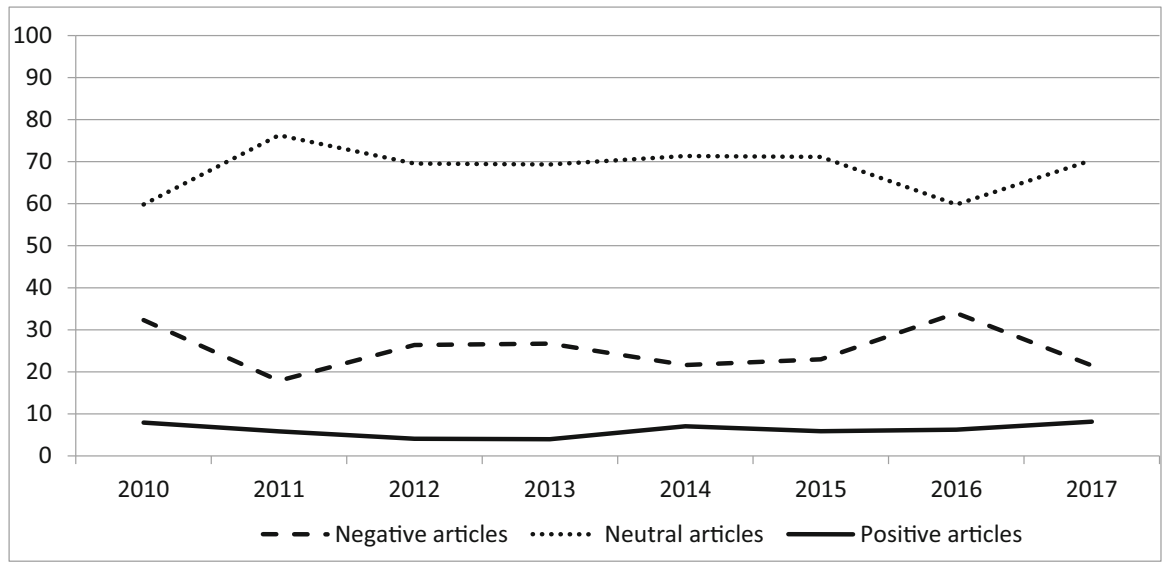

Fig. 5 Share of China-related articles in media according to sentiment (\% of articles)

thought that China is helping Slovakia to get the pandemic under control, while only $22 \%$ of Slovaks thought the same about the EU (Šnídl 2020).

A recent survey compiled by the Sinophone Borderlands project at Palacky University offers a deeper insight into the current perception of China (Turcsanyi et al. 2020). According to the survey, the view of the Slovak public towards China tends to be negative rather than positive. Over one-third of the population sees China negatively, while a quarter of the population had seen their views worsened in the past 3 years. At the same time, only less than a quarter of Slovaks have positive views of China, while only less than a fifth of Slovaks' views of China improved in the past 3 years (Fig. 3).

Altogether, almost half of the respondents' views have changed (both positively and negatively) in the past 3 years This suggests that the views of a large portion of the Slovak public are not firmly entrenched, but are rather dynamic. This echoes the findings of the Eurobarometer surveys (Fig. 4).

When it comes to political self-identification, there is a clear link between the people's perception of China and the positions of a political party with which they identify. The most negative perception of China can be found amongst the voters of Freedom and Solidarity $(\mathrm{SaS})$ and Progressive Slovakia parties which themselves are quite China-critical. On the opposite end, the voters of SMER-SD (and HLAS-SD) ${ }^{6}$ have the most favorable views of China.

\section{Conclusion}

Image of China in Slovakia still remains rather simplistic. Between 2010 and June 2017, majority of articles did not link more China-related topics together. This is largely due to most of the articles only reporting daily news without offering any analytical insight

\footnotetext{
${ }^{6}$ HLAS-SD is a social-democratic party which has been created after an internal cleavage of the SMER-SD party, which was established in September 2020. HLAS-SD is currently chaired by Peter Pellegrini, who between 2018 and 2020 served as Slovakia's Prime Minister nominated by the SMER-SD party.
} 
or commentary. However, the complexity of media coverage has been increasing slightly over time.

However, increasing complexity of the coverage did not translate much to change in perception of China, which over time still remained rather negative. Attempts by China to improve this perception did not have much influence on the public perception of China. This is most likely due to using inappropriate platforms to spread the Chinese views on specific issues. Media and public figures that are spreading pro-Chinese views do not garner much public trust as they tend to promote extremist views, be their extreme-left or extreme-right (Fig. 5).

The Slovak public, as evidenced by media coverage and opinion surveys, is still largely ambivalent towards China. Overall, the Slovak public's perception of China is slightly more negative than positive, with a large portion of the population being ambivalent towards the country. Yet, these views are quite dynamic and prone to change over time.

The same cannot be said about Slovak politicians. There appear to be three camps of views existing on the Slovak scene. Based on their overall views of China and determinants of these views, we can talk about pragmatic supporters, ideological supporters, and ideological opponents. This is a preliminary typology of Slovak politicians and political parties in their views of China. As such, this typology warrants future research.

Pragmatic supporters tend to view China solely in economic terms. They are willing to promote positive views of China as long as they think this will benefit Slovak trade and economic relations with China. Former Prime Minister Fico and current Prime Minister are examples of that camp.

Ideological supporters promote positive views of China out of their sincere belief that Chinese economic and political system is superior to that of the West (i.e., EU and NATO). Representatives subscribing to these views are to be found among extremists, be they from extreme left or extreme right.

Lastly, the ideological opponents tend to be found in the camps of what is nowadays termed "democratic opposition." These are parties that are not extremist in their nature and are not members of the current government of Slovakia. Their views are mostly determined by their support of democracy and human rights. As China is lacking in both, they tend to view China in negative light, since they equate views of China with its deficiencies in the two areas. These differences among political parties have a profound effect on their policies towards China. Under the governments led by SMER-SD, Slovak policy towards China tended to focus only on economic cooperation, and value-based political questions (e.g., human rights or security) were seen as a distraction. Following the 2020 parliamentary elections, when a government formed mostly of China-critical parties that assumed power, Slovakia has been regularly criticizing Chinese human rights abuses, disinformation, and propaganda in various international forums.

Differing views of China among political elites are mirrored by their electorates, as voters of parties belonging to the camp of ideological opponents tend to be more critical of China compared to the electorates of more China-friendly political parties. This division is not so much visible in the media coverage though. Economics clearly dominates the media discourse in Slovakia, while political topics lag behind. Moreover, Chinese official line is not managing to gain traction in the mainstream media so far. 
The high neutrality of media discourse should be conductive for a meaningful, constructive debate on Slovak policy towards China. The questions remains - will high exposure of Slovakia to China result in increased politicization and stereotyping of the public discourse on China? Only time will tell.

Funding The work was supported by the European Regional Development Fund Project "Sinophone Borderlands-Interaction at the Edges," CZ.02.1.01/0.0/0.0/16_019/0000791.

Data availability Data used in the study is available upon request from the author.

\section{Declarations}

Ethical approval All procedures performed in studies involving human participants were in accordance with the ethical standards of the institutional and/or national research committee and with the 1964 Helsinki declaration and its later amendments or comparable ethical standards.

Informed consent Informed consent was obtained from all individual participants included in the study.

Consent for publication Not applicable

Conflict of interest The authors declare no competing interests.

\section{References}

Balzacq T (2005) The three faces of securitization: political agency, audience and context. European Journal of International Relations 11(2):171-201

Beblavý M, Bilčík V, Roháč, D (n.d.) Úspešné Slovensko v neistom svete. SPOLU-občianska demokracia. https://stranaspolu.sk/admin/public/docs/uspesne.pdf. Accessed 30 July 2019.

Buzan B, Waever O, de Wilde J (1998) Security: a new framework for analysis. Lynne Rienner Publishers, London

Coban F (2016) The role of the media in international relations: from the CNN EFFECT to the Al-Jazeere effect. Journal of International Relations and Foreign Policy 4(2):45-61

Dai B (2010) Stick to the path of peaceful development. China Daily. December 13. http://www.chinadaily. com.cn/cndy/2010-12/13/content_11689670.htm. Accessed 30 July 2019.

Dubravčíková K et al. (2018) Chinese media watch: 16+1 \& EU-China Summit, Institute of Asian Studies. http://www.asian.sk/wp-content/uploads/2018/08/Media-Watch-16plus1.pdf. Accessed 30 July 2019.

European Commission (2016). Special Eurobarometer 451: Future of Europe.

European Commission (2017). Special Eurobarometer 467: Future of Europe.

European Commission (2018). Special Eurobarometer 479: Future of Europe.

Karásková I et al. (2018) Central Europe for sale: the politics of China’s influence. Asociace pro mezinárodní otázky. http://www.mapinfluence.eu/central-europe-for-sale-the-politics-of-chinas-influence-2/. Accessed 30 July 2019.

Lin L (2016a) Arbitrážny tribunál v otázke Juhočínskeho mora nie je legitímny. Nové slovo. 1 August https:// www.noveslovo.sk/c/Arbitrazny_tribunal_v_otazke_Juhocinskeho_mora_nie_je_legitimny. Accessed 30 July 2019.

Lin L (2016b) Vel'vyslanec Lin Lin o korupcii a vzt'ahoch Č́ny s prezidentom Kiskom i premiérom Ficom. Hlavné správy. 31 October. https://www.hlavnespravy.sk/velvyslanec-lin-lin-o-korupcii-a-vztahoch-cinys-prezidentom-kiskom-i-premierom-ficom/852497. Accessed 30 July 2019.

Lin L (2016c) Č́nsky vel'vyslanec na Slovensku Lin Lin o medzinárodnej politike, studenej vojne i "hre s nulovým súčtom”. Hlavné správy. 3 November. https://www.hlavnespravy.sk/cinsky-velvyslanec-na- 
slovensku-lin-lin-o-medzinarodnej-politike-studenej-vojne-i-hre-s-nulovym-suctom/853669. Accessed 30 July 2019.

Matura T (2015) China-CEE trade, investment and politics. UACES 45th Annual Conference, Bilbao, 7-9 September. https://www.uaces.org/documents/papers/1501/Matura.pdf. Accessed 30 July 2019.

Mesežnikov G, Pleschová G (2017) Testing democratic resolve in Slovakia. Sharp Power: Rising Authoritarian Influence. 5 December. https:/www.ned.org/wp-content/uploads/2017/12/Chapter5Sharp-Power-Rising-Authoritarian-Influence-Slovakia.pdf. Accessed 30 July 2019.

Parlamentné listy (2017) Slovenské médiá o Tibete šíria iba americkú propagandu, spustil Blaha. A takto to schytal od Chmelára a Poliačika. Parlamentné listy. 19 May. https:/www.parlamentnelisty.sk/arena/ monitor/Slovenske-media-o-Tibete-siria-iba-americku-propagandu-spustil-Blaha-A-takto-to-schytal-odChmelara-a-Poliacika-288245. Accessed 30 July 2019.

SITA (2017) Aktivisti vyzývajú štátne orgány, aby zasiahli proti výstave mŕtvych tiel. SME, 10 August. https:/domov.sme.sk/c/20623527/aktivisti-vyzyvaju-statne-organy-aby-zasiahli-proti-vystave-mrtvychtiel.html\#ixzz5RIPJ8yFi. Accessed 30 July 2019.

Šimalčík M (2018) After European funds dry out. Euractiv.com. 1 May. https://www.euractiv.com/section/ china/opinion/after-european-funds-dry-out-will-china-bring-better-tomorrows/. Accessed 30 July 2019.

Šimalčík M (2019) China’s fight against “erroneous opinions”. CHOICE. 3 September. https://chinaobservers. eu/chinas-fight-against-erroneous-opinions/. Accessed 6 October 2020.

Šnidl V (2020) Na Slovensko letia čínske respirátory. Na škatuliach sa píše o pomoci vo vetre a v daždi. Dennik N, 7 April. https://dennikn.sk/1843337/na-slovensko-leti-cinsky-dar-respiratorov-a-rusok-ktoryposluzi-aj-propagande/. Accessed 22 September 2020.

TASR (2014) Rozvinuli vlajku Tibetu. SME. 11 March, p. 6.

TASR (2016) "Už pocitujeme dôsledky stretnutia Kisku s dalajlámom," tvrdí Fico. Vel'ký investor sa odmlčal. Hospodárske noviny. 23 October. https://slovensko.hnonline.sk/847702-uz-pocitujemedosledky-stretnutia-kisku-s-dalajlamom-tvrdi-fico-velky-investor-sa-odmlcal. Accessed 30 July 2019.

Turcsányi R, Šimalčík M (2018) Čína na Slovensku: Sme pripravení na budúcnost'? Asociace pro mezinárodni otázky. 31 May. http://www.asian.sk/wp-content/uploads/2018/05/AMO_cina-naslovensku-sme-pripraveni-na-buducnost.pdf. Accessed 30 July 2019.

Turcsanyi R et al (2020) Sinophone Borderlands Europe Survey. Palacky University Olomouc

Uhrík M (2016) Oficiálna návšteva Č́nskej l’udovej republiky. Facebok post, July 13. https://www.facebook. com/pg/ing.milan.uhrik/photos/?tab=album\&album_id=292385864447866. Accessed 30 July 2019.

Xinhua (2018) China, CEE countries see steady trade growth in 2017. Xinhua. 2 June. http://www.xinhuanet. com/english/2018-06/02/c_137225245.htm. Accessed 30 July 2019.

Publisher's note Springer Nature remains neutral with regard to jurisdictional claims in published maps and institutional affiliations. 